\title{
Advanced Catalytic Membrane Characterisation and Gas Permeation Properties for Enhanced Ethyl Lactate Conversion
}

\author{
Edidiong Okon, Habiba Shehu, Ifeyinwa Orakwe, Edward Gobina* \\ Center for Process Integration and Membrane Technology, School of Engineering, the Robert Gordon University, Aberdeen, UK \\ Email: *e.gobina@rgu.ac.uk
}

How to cite this paper: Okon, E., Shehu, H., Orakwe, I. and Edward, G. (2017) Advanced Catalytic Membrane Characterisation and Gas Permeation Properties for Enhanced Ethyl Lactate Conversion. Journal of Materials Science and Chemical Engineering, 5, 1-16.

http://doi.org/10.4236/msce.2017.53001

Received: January 24, 2017

Accepted: March 28, 2017

Published: March 31, 2017

Copyright $\odot 2017$ by authors and Scientific Research Publishing Inc. This work is licensed under the Creative Commons Attribution International License (CC BY 4.0).

http://creativecommons.org/licenses/by/4.0/

\begin{abstract}
In this work, membrane evaluation, gas permeation properties and characterisation have been presented. A silica composite membrane was prepared, characterized and used for the permeation tests with four carrier gases to determine the most suitable carrier gas for enhancing the analysis of esterification product with gas chromatograph. The carrier gases used for the permeation tests were carbon dioxide $\left(\mathrm{CO}_{2}\right)$, argon ( $\left.\mathrm{Ar}\right)$, helium $(\mathrm{He})$ and nitrogen $\left(\mathrm{N}_{2}\right)$. The permeation analysis was carried out between the gauge pressure range of $0.10-1.00$ bar and temperature of $60^{\circ} \mathrm{C}$. The gas flow rate was found to increase with respect to gauge pressure. The order of the gas flow rate with respect to the gauge pressure was $\mathrm{Ar}>\mathrm{CO}_{2}>\mathrm{He}>\mathrm{N}_{2}$. The surface morphology and elemental composition of the membrane were analysed using scanning electron microscopy coupled with energy dispersive analysis of $\mathrm{x}$-ray (the Zeiss EVO LS10). The SEM results exhibited a defect-free surface while the EDAX results identified different elements on the spectra including titanium (Ti), silicon ( $\mathrm{Si}$ ) and oxygen $(\mathrm{O})$. Liquid nitrogen adsorption method (Quantachrome 2013 model) was used for the surface area and pore size distribution analysis. The Brunauer-Emmette-Teller (BET) surface area results of the $5^{\text {th }}$ and $6^{\text {th }}$ dip-coated membranes were 1.497 and $0.253 \mathrm{~m}^{2} / \mathrm{g}$ respectively, while the Barrette-Joyner-Halender (BJH) curves gave a pore size of 4.184 and 4.180 $\mathrm{nm}$ respectively for the $5^{\text {th }}$ and $6^{\text {th }}$ dip-coated membranes indicating a mesoporous structure. The BET curve exhibited a type IV isotherm. The BJH curve of the $6^{\text {th }}$ dip-coated membrane showed a significant reduction in flow rate after the modification process. The membrane recorded a permeance in the range of $1.03 \times 10^{-6}$ to $9.32 \times 10^{-7} \mathrm{~mol} \cdot \mathrm{m}^{-2} \cdot \mathrm{s}^{-1} \cdot \mathrm{Pa}^{-1}$. The permeance relationship with the inverse square root of the gas molecular weight showed a linear proportionality with the flow of carrier gases confirming Knudsen flow mechanism of gas transport.
\end{abstract}




\section{Keywords}

Permeation, Characterisation, Inorganic Membrane, Carrier Gas Transport, Esterification and Adsorption Isotherm

\section{Introduction}

Membrane technologies have found application in diverse industrial applications including biotechnology, food and pharmaceutical industries. They can also be used for the treatment of industrial effluents. Membranes are also used in different processes such as microfiltration, nanofiltration, and ultrafiltration offering a range of separations which may be used to recover, purify and concentrate valuable solvents in industry [1]. Although membranes possess numerous advantages, they also exhibit a major drawback such as fouling. Fouling is the major problem in membrane process as it reduces the membrane performance resulting in high running costs, which are largely the biggest costs in the membrane industrial plant [1]. In order to reduce the influence of fouling on membranes, different methods including mechanical and chemical cleaning process have been designed. When characterising the membrane, the pore size distribution are normally obtained using liquid nitrogen adsorption/desorption analysis while the morphological characteristics could be obtained using scanning electron microscopy method [1] [2]. Other information could also be obtained from the gas permeability measurement. Membranes may be classified into organic and inorganic categories and the different configurations include: Dense, porous and composite membranes [3]. Currently, ceramic porous inorganic membranes have been widely employed in different fields such as chemical and petrochemical, bioengineering and environmental engineering. Compared to other membranes, ceramic membranes have higher thermal and chemical stability [4].

Membranes of different shapes and characteristics are generally made from a wide variety of chemically and thermally stable precursors. Other materials including alumina $\left(\mathrm{Al}_{2} \mathrm{O}_{3}\right)$, titania $\left(\mathrm{TiO}_{2}\right)$, zirconia $\left(\mathrm{ZrO}_{2}\right)$ and silica $\left(\mathrm{SiO}_{2}\right)$ are also being used [5]. Silica membranes have attracted a lot of attention in the gas separation industries because they are thermally and chemically stable in contrast to polymeric membranes. They can offer higher permeability and selectivity for small gas molecules including $\mathrm{He}$ and $\mathrm{H}_{2}$ over larger molecules like $\mathrm{CO}_{2}, \mathrm{~N}_{2}$ and $\mathrm{C}_{3} \mathrm{H}_{8}$ gases. Different modification methods can be employed for the preparation of membranes including sol-gel dip-coating, chemical vapour deposition and sintering. The sol-gel method involves the formation and deposition of a suitable sol, like colloidal boehmite onto a porous support followed by drying and thermal treatment [6]. Sol-gel dip-coating method has been widely employed for the formation of silica and alumina-based inorganic membranes [7]. Membranes prepared using this method usually exhibit higher permeance in contrast to those prepared with the chemical vapour deposition methods. Inorganic membrane may be classified based on their pore size as macrospores ( $>500 \AA$ ), mi- 
cropores $(20 \AA)$ and mesopores $(20$ - $500 \AA$ ) [8]. Gas transport in inorganic membranes may be explained using various mechanism of transport through the pore. The different transport mechanisms include Knudsen, viscous, capillary condensation, molecular sieving and surface diffusion mechanisms. Knudsen transport takes place when the mean free path of the gas molecules is greater than the pore size. In this case, there are more collisions between the molecules than the pore walls. However, separation selectivities in this mechanism are proportional to the ratio of the inverse square root of the gas molecular weight. Knudsen flow mechanism is usually predominant in mesoporous and macroporous membranes [6] [8].

The expression for Knudsen flow in porous membrane can be written using the following equation [8]:

$$
D=\frac{\varepsilon \delta \rho}{3 \tau}\left(\frac{8 R T}{\pi M}\right)^{1 / 2}
$$

where $D$ is the Knudsen diffusion $\left(\mathrm{m}^{2} / \mathrm{s}\right), \varepsilon=$ porosity of the membrane (\%), $R$ = gas molar constant $\left(\mathrm{J} \cdot \mathrm{mol}^{-1} \cdot \mathrm{K}^{-1}\right), \quad M=$ the molar weight of the diffusing gas $(\mathrm{g} / \mathrm{mol}), \mathrm{d} p=$ pore diameter $(\mathrm{m}), \tau=$ tortuosity $(\mathrm{m})$ and $T=$ temperature (K), $\pi=2.134$.

The mean free path of the gas molecule is the average distance travelled in collisions and can be explained using the equation [9].

$$
\lambda=\frac{k T}{\sqrt{2} \pi \mathrm{d}^{2} P}
$$

where $\lambda$ is the mean free path (m), $k$ is the Boltzmann constant $\left(\mathrm{J} \cdot \mathrm{K}^{-1}\right), T$ is temperature $(\mathrm{K}), \mathrm{d}$ is the collision diameter $(\mathrm{m})$ and $P$ is the pressure $(\mathrm{Pa})$ [9].

Viscous flow mechanism takes place if the pore radius of the membrane is greater than the mean free path of the permeating gas molecule [10] [11]. In this case more collisions will take place between the permeating gas molecules (molecule-molecule collision) than between the molecule and the pore wall of the membrane and viscous flow will dominate [10].

The viscous flow mechanism of gas transport can then be expressed as:

$$
F_{\text {viscous }}=\frac{r_{p}^{2}\left(P_{1-} P_{2}\right)}{16 L \mu R T}\left(\frac{\mathrm{mol}}{\mathrm{m}^{2} \cdot \mathrm{s}}\right)
$$

where $P_{1}=$ absolute pressure $(\mathrm{Pa}), P_{2}=$ atmospheric pressure $(\mathrm{Pa}), \mu=$ gas viscosity $\left(\mathrm{Pa} \cdot \mathrm{s}^{-1}\right), L=$ membrane wall thickness $(\mathrm{m}), r=$ membrane pore size (m), $R=$ gas molar constant $\left(\mathrm{J} \cdot \mathrm{mol}^{-1} \cdot \mathrm{K}^{-1}\right), T=$ atmospheric temperature $(\mathrm{K})$ [10].

Gas separation by molecular sieving mechanism takes place when the pore diameter of the inorganic ceramic membrane is roughly the same as those of the permeating gas molecules [12] [13]. However, as the pores become smaller than approximately $0.5 \mathrm{~nm}$, separation factors greater than 10 are usually achievable. If the pore size of the membrane is between the diameters of the larger and smaller gas molecules, then only the smaller gas molecule can permeate through the membrane leading to a more efficient separation [10] [14]. In the capillary 
condensation mechanism, separation takes place in the pores of the membrane with mesoporous layer in the presence of condensable gas specie such as water vapour [11]. The condensed feed component diffuses through the pores of the membrane blocking other components resulting in separation [15]. Surface diffusion mechanism of transport occur when the gas molecule exhibit a strong affinity for the membrane surface and adsorption along the pore walls. However, separation in this mechanism takes place due to differences in the amount of adsorption of the permeating molecules.

According to IUPAC (International Union of Pure and Applied Chemistry), the major physisorption isotherms can be classified into six different types [16]. However, the most important isotherm for a porous membrane material is the type 1 isotherm which relates to the microporous solids and type IV and V, which corresponds to mesoporous solid (most especially ceramic materials which undergo hysteresis and capillary condensation during desorption. The use of adsorption/desorption isotherms to characterise porous ceramic membrane materials possesses major drawback despite its widespread application in various analytical techniques. The different types of physisorption isotherms and hysteresis are explained as shown in Figure 1(a) and Figure 1(b) respectively [2].

In this study, the characterisation and evaluation of a silica membrane with 15 $\mathrm{nm}$ pore size was investigated to determine the permeation properties of single gases $\mathrm{Ar}, \mathrm{He}, \mathrm{N}_{2}$ and $\mathrm{CO}_{2}$ with inorganic composite membrane for the esterification reactions.

\section{Experimental}

\subsection{Membrane Preparation}

The membrane preparation was carried out based on the dip-coating process patented by Gobina [17]. Prior to the permeation tests, the support was weighed to determine the actual weight before and after modification. $545 \mathrm{~mL}$ of isopentane (Sigma Aldrich $\geq 99 \%$ ), was measured into $1000 \mathrm{~mL}$ glass cylinder and $50 \mathrm{~mL}$ of silicon elastomer was added to the solution together with $5 \mathrm{~mL}$ of the

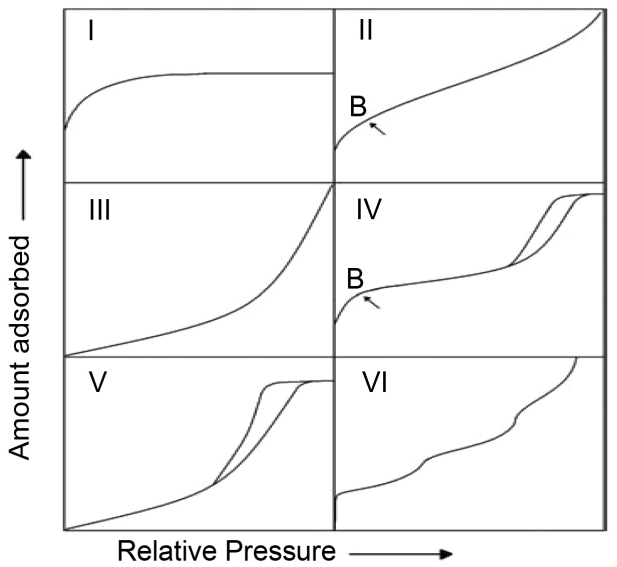

(a)

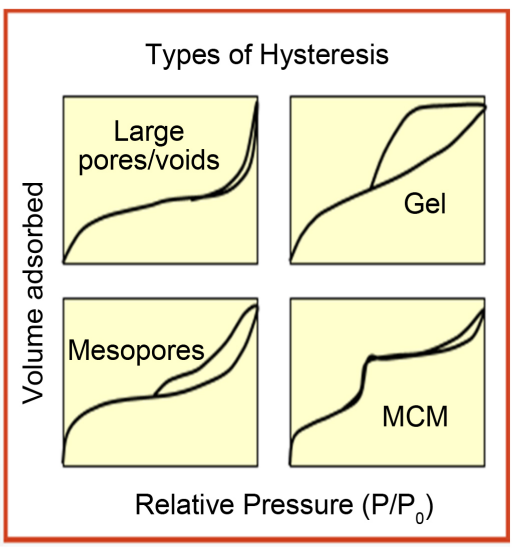

(b)

Figure 1. Types of physisorption isotherms (a) and types of hysteresis (b). 
curing agent. A magnetic stirrer was used to mix the three solutions and the mixture was allowed to stir for 30 minutes. After this period the support was withdrawn the solution and allowed in the solution for 30 minutes. After 30 minutes, the support was taken out from the solution and dried in the oven for 2 hrs at a constant temperature of $65^{\circ} \mathrm{C}$ in order to obtain an ultra-thin silica layer on the support. The support modification process was carried out based on the patented innovation by Gobina (2006) [17] [18]. Figure 2 shows the schematic diagram of the dip-coating process.

The membrane thickness after modification was calculated using the following formula [19].

$$
L=\frac{W_{2}-W_{1}}{A \rho(1-\varepsilon)}
$$

where $L=$ membrane thickness $(\mathrm{m}), A=$ membrane area $\left(\mathrm{m}^{2}\right), \rho=$ theoretical density of alumina $\left(3.95 \times 10^{-3} \mathrm{~kg} \cdot \mathrm{m}^{-3}\right), W_{1}=$ initial weight of the alumina support (g), $\varepsilon=$ membrane porosity (\%), $W_{2}=$ total weight of the support and membrane (g).

\subsection{Permeation Cell}

The permeation cell consisted of a thermally resistant stainless steel shell. The membrane was centralized in the tube using a graphite seal each at either end. Through the use of various connections and valves the cell permits the measurement of the gas flux through the membrane at various feed pressures. A heating tape was wrapped over the stainless steel reactor which enables hightemperature studies to be carried out. Prior to permeation experiments, a leak test was carried out by monitoring the downstream pressure variation while the system remained totally closed and pressurized.

\subsection{Permeation Tests}

The four gases used for the permeation analysis include nitrogen $\left(\mathrm{N}_{2}\right)$, argon

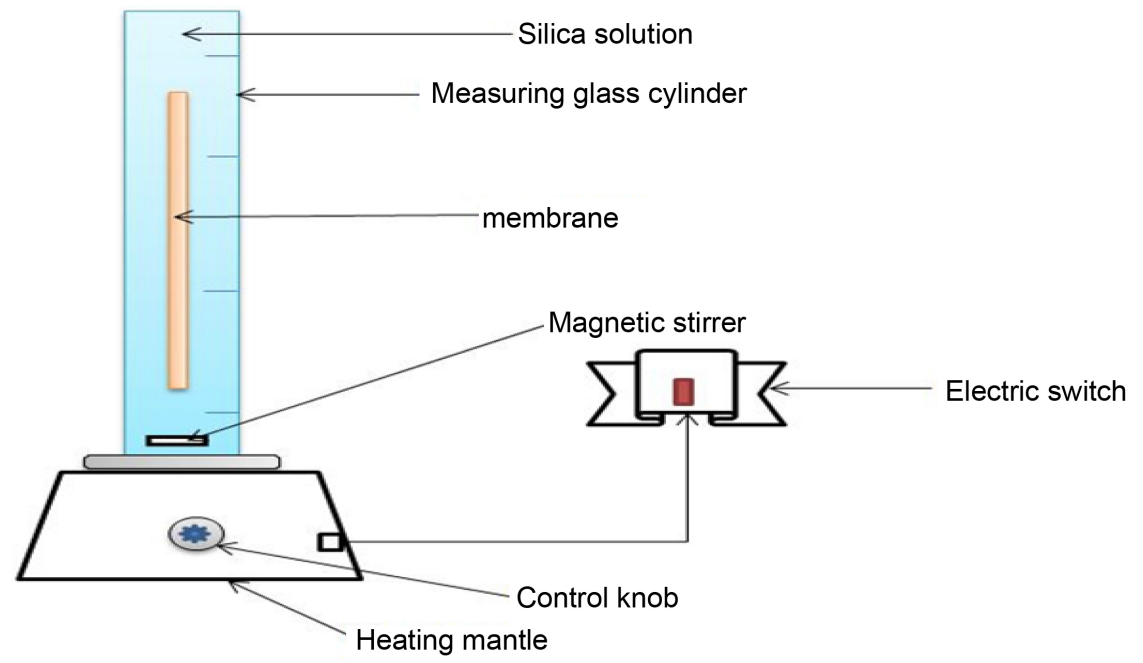

Figure 2. Schematic diagram of gas permeation setup. 
(Ar), helium ( $\mathrm{He})$ and carbon dioxide $\left(\mathrm{CO}_{2}\right)$. The gases were supplied by BOC, UK. The permeation analysis was carried out at a feed pressure drop of between $0.10-1.00$ bar and at $60^{\circ} \mathrm{C}$. This gauge pressure scale and the temperature were chosen to correspond with the esterification reaction parameters for the analysis of the ester product. The total length of the membrane was $36.6 \mathrm{~cm}$, while the inner and outer radius of the membrane was 7 and $10 \mathrm{~mm}$ respectively. Figure 3 shows the single gas permeation setup.

\subsection{Liquid Nitrogen Adsorption}

The surface area analysis of the support and coated support was examined using liquid nitrogen adsorption instrument shown in Figure 4. Prior to the analysis, a

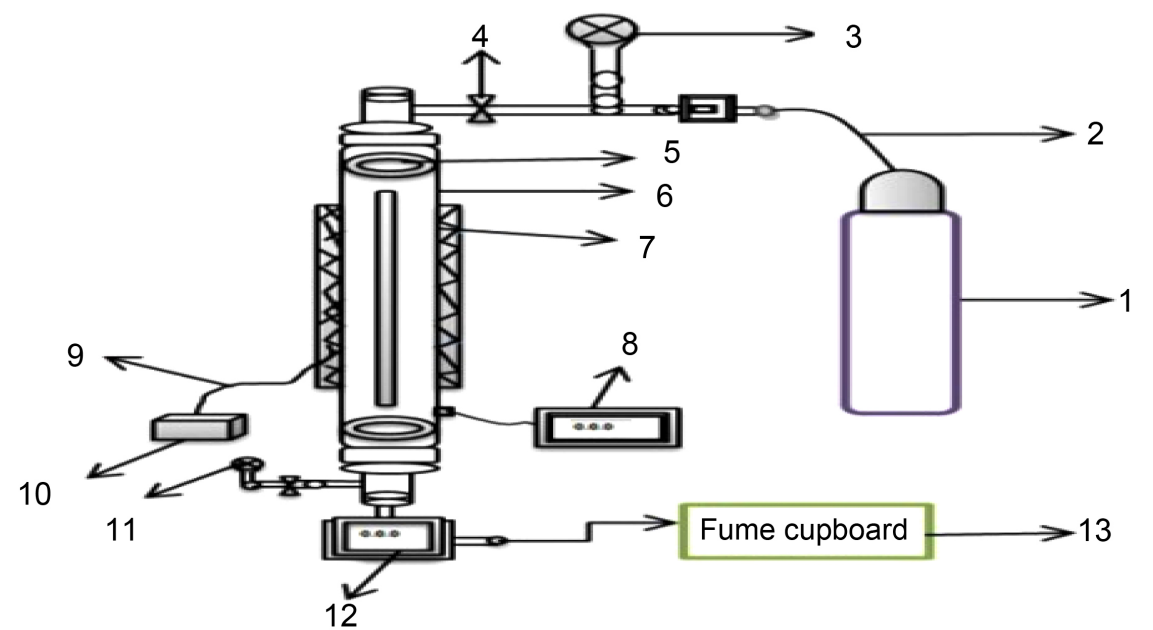

Figure 3. Schematic diagram of gas permeation setup which consists of; carrier gas cylinder (1), gas feed inlet (2), permeate pressure gauge (3), control valve (4), O-ring graphite seal (5), reactor (6), heating tape (7), temperature regulator (8), thermocouple (9), thermocouple box (10), retentate pressure gauge (11), flow meter (12) and fume cupboard (13)

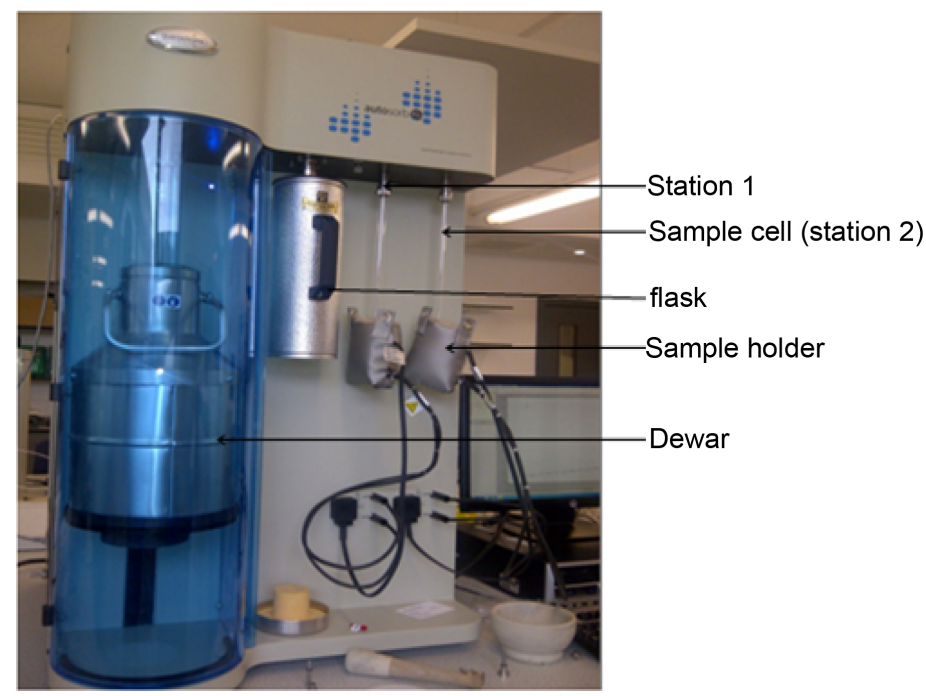

Figure 4. Liquid nitrogen adsorption (Quantachrome 2013 model). 
small fragment of the silica membrane was crushed and used for the liquid nitrogen analysis. The actual weight of the $5^{\text {th }}$ and $6^{\text {th }}$ dipping membrane samples was $4.3 \mathrm{~g}$ and $4.2 \mathrm{~g}$ respectively. The sample cell weight for the $5^{\text {th }}$ and $6^{\text {th }}$ dipping was $16.8 \mathrm{~g}$ and $27.7 \mathrm{~g}$ respectively. The degassing of the system was carried out using a flow of dry helium gas with heating in order to remove moisture from the sample. A similar procedure to that of Vospernik et al. [20] was used for the liquid nitrogen analysis with some modification in the temperature. The liquid nitrogen temperature was $77 \mathrm{~K}$. The actual weights of the silica membranes, the cell weight and the weight of sample + cell before and after the degassing process are presented in Table 1.

\subsection{Scanning Electron Microscopy/Energy Dispersive $X$-Ray Analyser (SEM/EDAX)}

The surface examination of the membranes was carried out the Zeiss EVO LS10 SEM/EDAX between the scale range of $10-100 \mu \mathrm{m}$. The images were analysed at the magnification of $100 \times$ at the working distance of $8.5 \mathrm{~mm}$ while the chamber pressure was set between the range of 100 - 101 Pa. Figure 5 shows the SEM/EDAX instrument that was used for the membrane morphological characterisation.

Table 1. Sample and cell weights before and after degassing process.

\begin{tabular}{ccccc}
\hline Sample & $\begin{array}{c}\text { Cell weight } \\
(\mathrm{g})\end{array}$ & $\begin{array}{c}\text { Weight of } \\
\text { sample + cell } \\
\text { before } \\
\text { degassing(g) }\end{array}$ & $\begin{array}{c}\text { Actual weight of } \\
\text { sample (g) }\end{array}$ & $\begin{array}{c}\text { Weight of sample } \\
\text { after degassing (g) }\end{array}$ \\
\cline { 3 - 5 } $5^{\text {th }}$ dipping & 16.8 & 21.1 & 4.3 & 21.0 \\
$6^{\text {th }}$ dipping & 27.7 & 31.9 & 4.2 & 31.8 \\
\hline
\end{tabular}

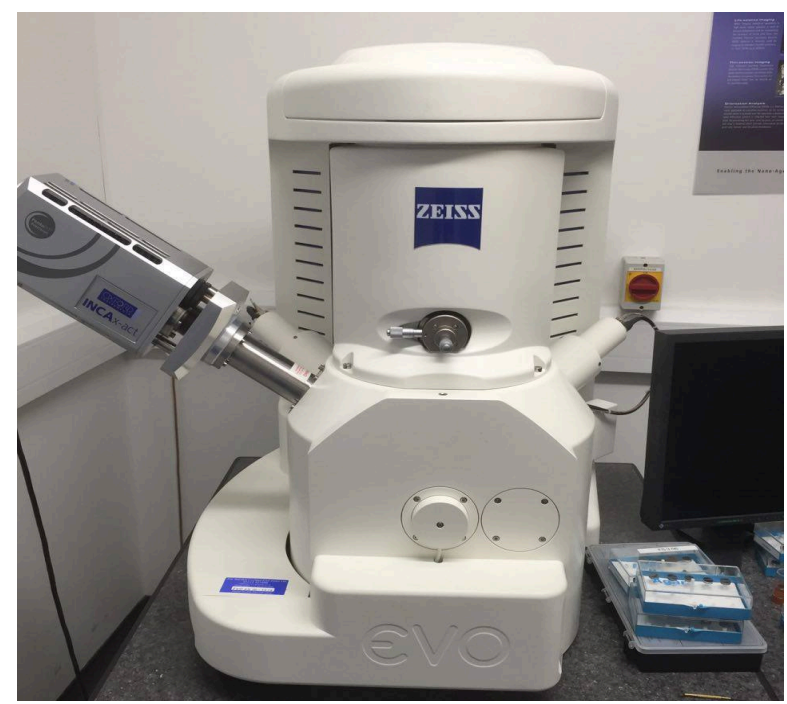

Figure 5. Scanning electron microscope couple with energy $X$-ray dispersive analyser (SEM/EDAX) (the Zeiss EVO LS10) instrument. 


\section{Result and Discussion}

\subsection{Permeation Test}

Figure 6 shows the relationship between the flow rate of the different gases and the gauge pressure at $60^{\circ} \mathrm{C}$. From Figure 6 , it can be seen that the flow rate of the gases increases with an increase in the gauge pressure. However, at a particular pressure the flow difference was explained based on the molecular weight of the different gases. It was found that helium gas with the least molecular weight ( $2 \mathrm{~g} / \mathrm{mol}$ ) exhibited the highest flow in contrast to other gases. It was assumed that the gas flow was dominated by Knudsen mechanism of gas transport which explains that gases with the less molecular weight permeate through the membrane faster than the gases with higher molecular weight. It was also observed that the flow rate for $\mathrm{Ar}, \mathrm{N}_{2}$ and $\mathrm{CO}_{2}$ were close to each other over the pressure range investigated. Although they exhibited a similar flow, $\mathrm{N}_{2}$ with the least a lower molecular weight $(28 \mathrm{~g} / \mathrm{mol})$ showed a higher flow than $\operatorname{Ar}(40 \mathrm{~g} / \mathrm{mol})$ and $\mathrm{CO}_{2}(44 \mathrm{~g} / \mathrm{mol})$ and can be seen that the gas flow rate was based on their respective molecular weight in accordance with the Knudsen mechanism. The order of the gas flow rate with respect to a particular gauge pressure was $\mathrm{He}(2 \mathrm{~g} / \mathrm{mol})>$ $\mathrm{N}_{2}(28 \mathrm{~g} / \mathrm{mol})>\operatorname{Ar}(40 \mathrm{~g} / \mathrm{mol})>\mathrm{CO}_{2}(44 \mathrm{~g} / \mathrm{mol})$. This also confirms the fact that helium could be a suitable carrier gas for the analysis of the esterification reaction product using gas chromatograph for improved ethyl lactate conversion.

Figure 7 describes the relationship between the gas permeance and the gauge pressure (bar). From Figure 7, it was found that the permeance of the gases decreases with respect to the gauge pressure but the rate of decrease was less pronounced at a gauge pressure of greater than 0.4 bars. A similar result was also observed in our previous study [21]. Also from Figure 7, it was found that the statistical error bars for the gases showed good significant value of the experimental data.

The permeance of $\mathrm{Ar}, \mathrm{He}, \mathrm{CO}_{2}$ and $\mathrm{N}_{2}$ was calculated using Equation (5):

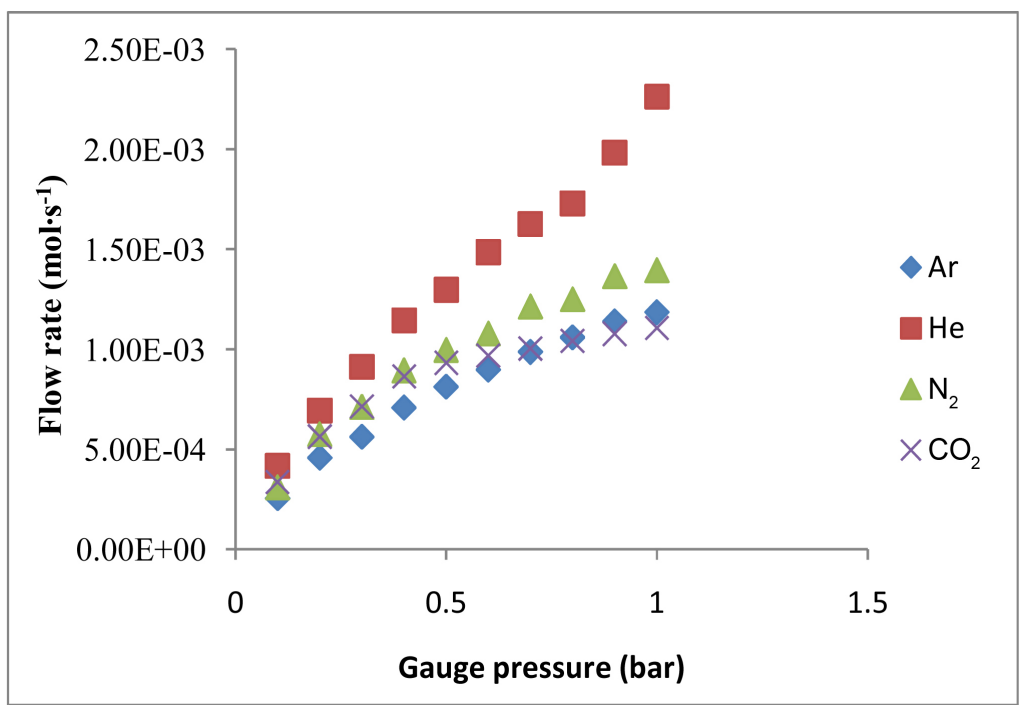

Figure 6. Gas Flow rate $\left(\mathrm{mol} \cdot \mathrm{s}^{-1}\right)$ against gauge pressure (bar) at $60^{\circ} \mathrm{C}$. 


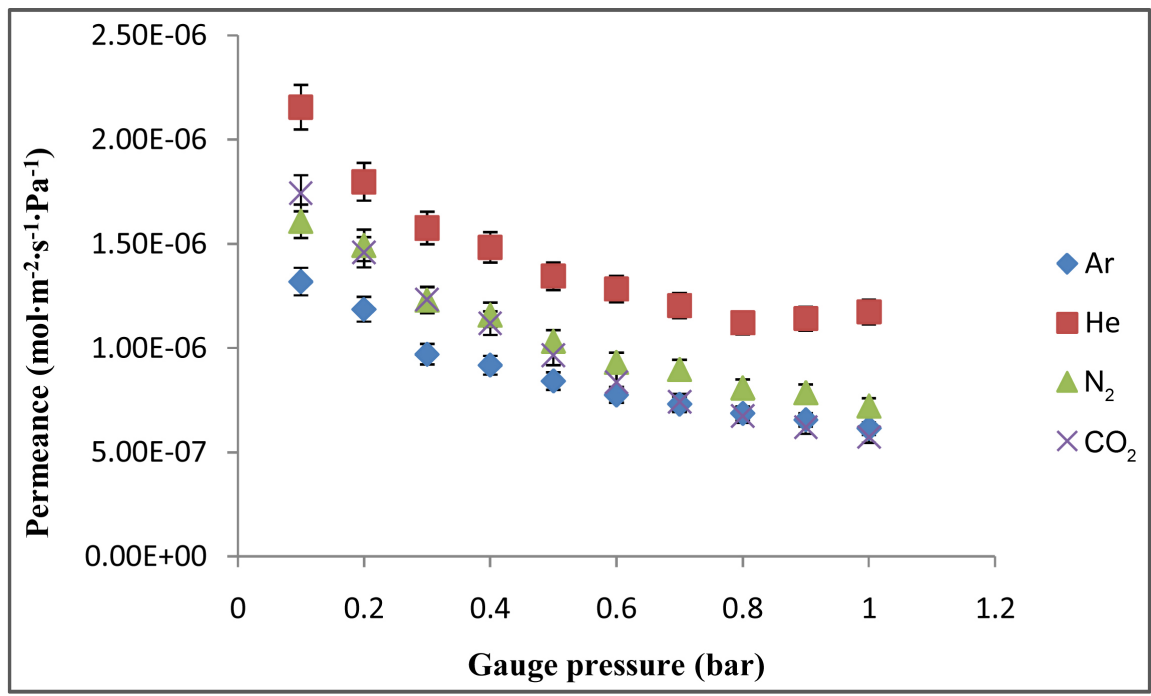

Figure 7. Gas permeance $\left(\mathrm{mol} \cdot \mathrm{m}^{-2} \cdot \mathrm{s}^{-1} \cdot \mathrm{Pa}^{-1}\right)$ against gauge pressure (bar) at $60^{\circ} \mathrm{C}$.

$$
Q_{i}=\frac{J}{\Delta P}
$$

where $Q_{i}=$ gas permeance $\left(\mathrm{mol} \cdot \mathrm{m}^{-2} \cdot \mathrm{s}^{-1} \cdot \mathrm{Pa}^{-1}\right), \Delta P=$ pressure drop across the membrane (bar) and $J=$ Gas flux $\left(\mathrm{mol} \cdot \mathrm{m}^{-2} \cdot \mathrm{s}^{-1}\right)$. The mean free paths of the four gases were calculated using Equation (2). The permeability of the membrane was further calculated by multiplying the permeance (Equation (5)) with the thickness of the membrane that was calculated using Equation (4). The formula for the membrane permeability is given by Equation (6):

$$
F=\frac{J}{\Delta P} \times L
$$

The pore size of the membrane was calculated using Equation (7):

$$
\tau_{p}=\frac{16 \cdot A o \cdot \mu}{3 \cdot B} \sqrt{ } \frac{8 R T}{\pi M}
$$

where $\tau_{p}=$ membrane pore radius $(\mathrm{m})$, Ao $=$ constant representing viscous flow from the permeability graph, $B=$ constant representing Knudsen flow from the permeability graph, $\mu=$ gas viscosity $\left(\mathrm{Pa} \cdot \mathrm{s}^{-1}\right), \pi=3.142, M=$ gas molecular weight $(\mathrm{g} / \mathrm{mol}), T=$ temperature $(\mathrm{K}), R=$ gas molar constant $(\mathrm{K} \cdot \mathrm{J} \cdot \mathrm{mol})$.

The membrane permeability, mean free path, and pore radius for four gases were calculated as shown in Table 2. From the result obtained in Table 2, it was found that the pore radius of the membrane was smaller than the mean free path which confirms the Knudsen flow mechanism of transport. This result was in accordance with a report by Benito et al. [22] which explains that Knudsen diffusion is dominant if the membrane pore radius is smaller than the mean free path of the gas molecules and this is also significant for membrane with small pore radius of $<10 \mathrm{~nm}$ and defect-free membranes [14] [22] [23]. It can also be seen from Table 2 that $\mathrm{He}$ and $\mathrm{CO}_{2}$ gases recorded a higher permeability values in contrast to $\mathrm{N}_{2}$ and Ar gases although the permeability value of $\mathrm{CO}_{2}$ and $\mathrm{N}_{2}$ gases were quite close. 
Table 2. Calculated values of permeability, mean free path and pore radius of the silica membrane with $\mathrm{Ar}, \mathrm{He}, \mathrm{CO}_{2}$ and $\mathrm{N}_{2}$ gases.

\begin{tabular}{cccc}
\hline Gas molecule & $\begin{array}{c}\text { Mean free } \\
\text { path }(\lambda) \mathrm{m}\end{array}$ & Pore radius $(\mathrm{m})$ & $\begin{array}{c}\text { Permeability } \\
\left(\mathrm{mol} \cdot \mathrm{m} \cdot \mathrm{m}^{-2} \cdot \mathrm{s}^{-1} \cdot \mathrm{Pa}^{-1}\right)\end{array}$ \\
\hline $\mathrm{Ar}$ & $3.15 \mathrm{E}-04$ & $4.72 \mathrm{E}-12$ & $3.67 \mathrm{E}-08$ \\
$\mathrm{He}$ & $3.63 \mathrm{E}-04$ & $1.09 \mathrm{E}-11$ & $5.92 \mathrm{E}-08$ \\
$\mathrm{~N}_{2}$ & $2.96 \mathrm{E}-04$ & $4.45 \mathrm{E}-12$ & $4.48 \mathrm{E}-08$ \\
$\mathrm{CO}_{2}$ & $1.11 \mathrm{E}-04$ & $2.22 \mathrm{E}-12$ & $4.64 \mathrm{E}-08$ \\
\hline
\end{tabular}

Figure 8 presents the relationship between the gas permeance and the inverse square root of the gas molecular weight at 0.30 bar and $60^{\circ} \mathrm{C}$. From the result obtained, it was found that $\mathrm{Ar}, \mathrm{N}_{2}$ and $\mathrm{CO}_{2}$ gases showed a linear proportionality with the inverse square root of the gas molecular weight which was in accordance with the Knudsen law of diffusion of gases through the pores of the membrane, whereas helium gas exhibited a deviation from the linear line [21], suggesting that another flow mechanism was in operation for $\mathrm{He}$ gas at $0.30 \mathrm{bar}$ and $60^{\circ} \mathrm{C}$. The suggested flow mechanism was viscous plus surface diffusion mechanism as these two mechanisms are also said to be controlling rate mechanism of transport in mesoporous membrane. Since the helium gas did not display the evidence of Knudsen flow mechanism, it was suggested that viscous plus surface diffusion mechanism was the additional transport mechanism. The order of the gas permeance with respect to the inverse square root of the gas molecular weight was given as $\mathrm{He}>\mathrm{N}_{2}>\mathrm{CO}_{2}>\mathrm{Ar}$.

\subsection{Liquid Nitrogen Results}

A summary of the various parameters obtained from the liquid nitrogen characterisation for the $5^{\text {th }}$ and $6^{\text {th }}$ dip-coating are presented in Table 3. Figure 9 and Figure 10 describe the relationship between the volume and the relative pressure for the modified silica membrane. From the results obtained in Figure 9 and Figure 10 it was found that the BET of the $5^{\text {th }}$ dip-coated membrane exhibited a higher surface area $\left(2.916 \mathrm{~m}^{2} / \mathrm{g}\right)$ in contrast to the $6^{\text {th }}\left(0.088 \mathrm{~m}^{2} / \mathrm{g}\right)$ as shown in Table 3. It was also observed that there was hysteresis on the curves although the hysteresis on the $6^{\text {th }}$ dip-coated membrane was more pronounced in contrast to that of the $5^{\text {th }}$ dip-coated membrane [24]. The BJH of the twice-dipped membranes were also compared. From the $\mathrm{BJH}$ results of the twice dipped membranes, it was found that there was reduction on the pore size of the membrane after the modification process [25]. This was attributed to the silica that was used in the membrane modification process. Although the pore of the $6^{\text {th }}$ dipcoated membrane was found to have reduced, the total pore size of the $5^{\text {th }}$ and $6^{\text {th }}$ dip-coated membranes were believed to be within the mesoporous range according to the IUPAC classification.

\subsection{SEM/EDAX of the Membrane}

Figure 11 shows the SEM/EDAX of the membrane. From Figure 11, it can be 


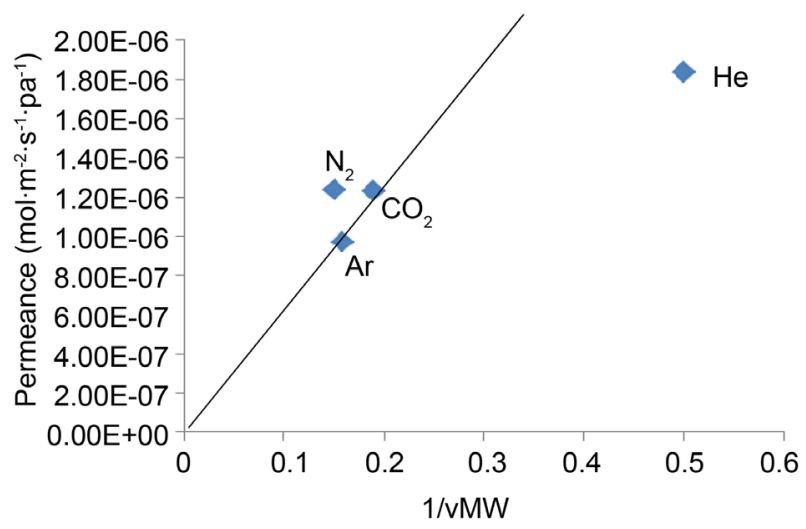

Figure 8. Gas permeance $\left(\mathrm{mol} \cdot \mathrm{m}^{-2} \cdot \mathrm{s}^{-1} \cdot \mathrm{Pa}^{-1}\right)$ against inverse square root of the gas molecular weight $(\mathrm{g} / \mathrm{mol})$ at $0.40 \mathrm{bar}$ and $60^{\circ} \mathrm{C}$.

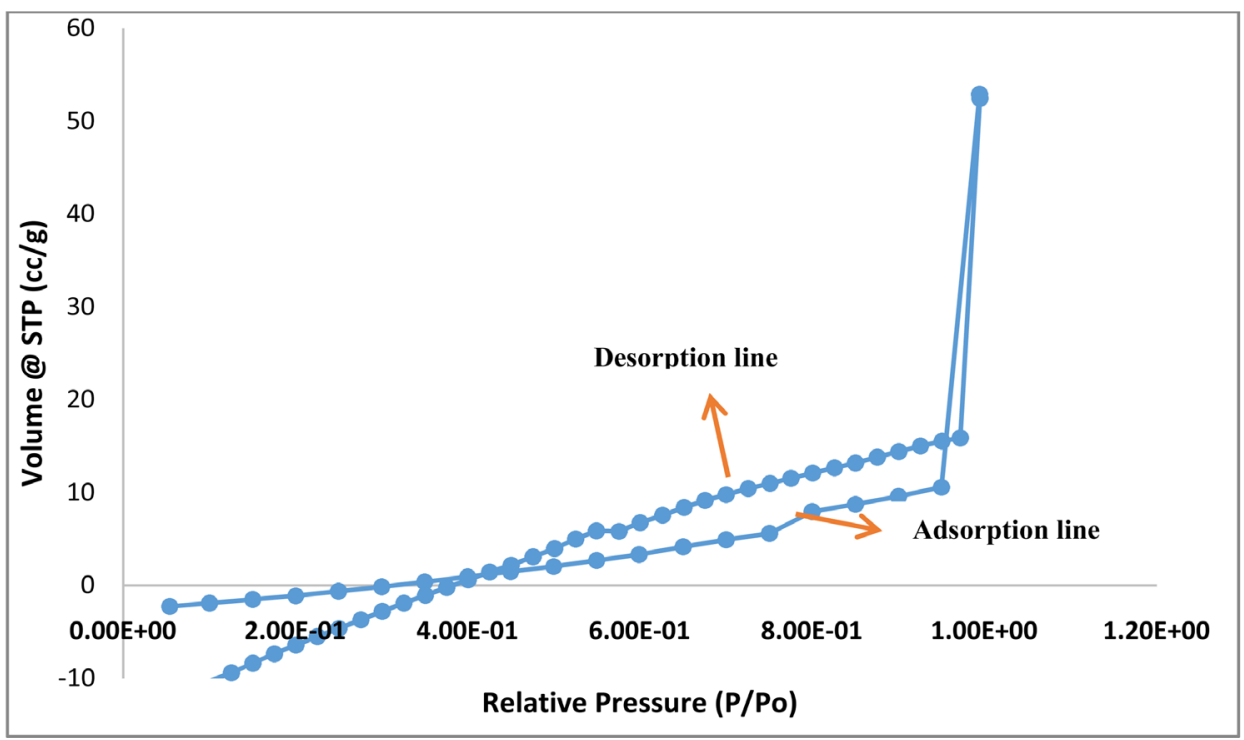

Figure 9. BET surface area of the $5^{\text {th }}$ dip-coated membrane.

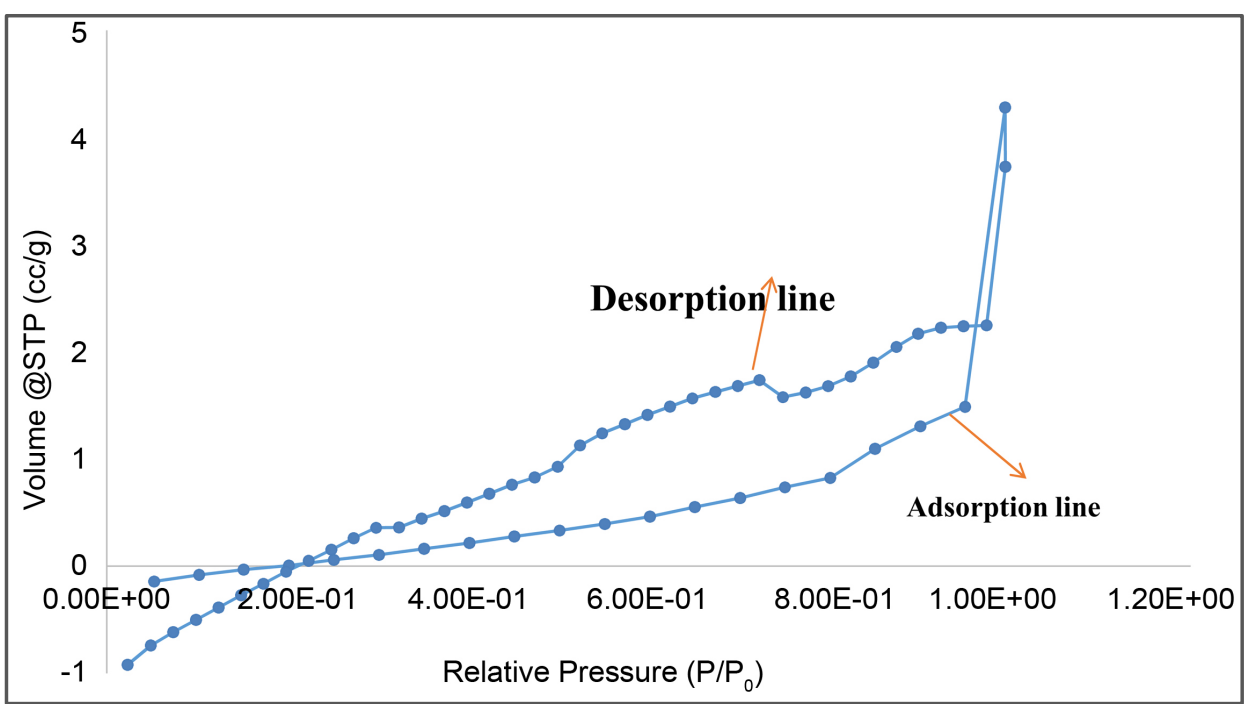

Figure 10. BET surface area of the $6^{\text {th }}$ dip-coated membrane. 


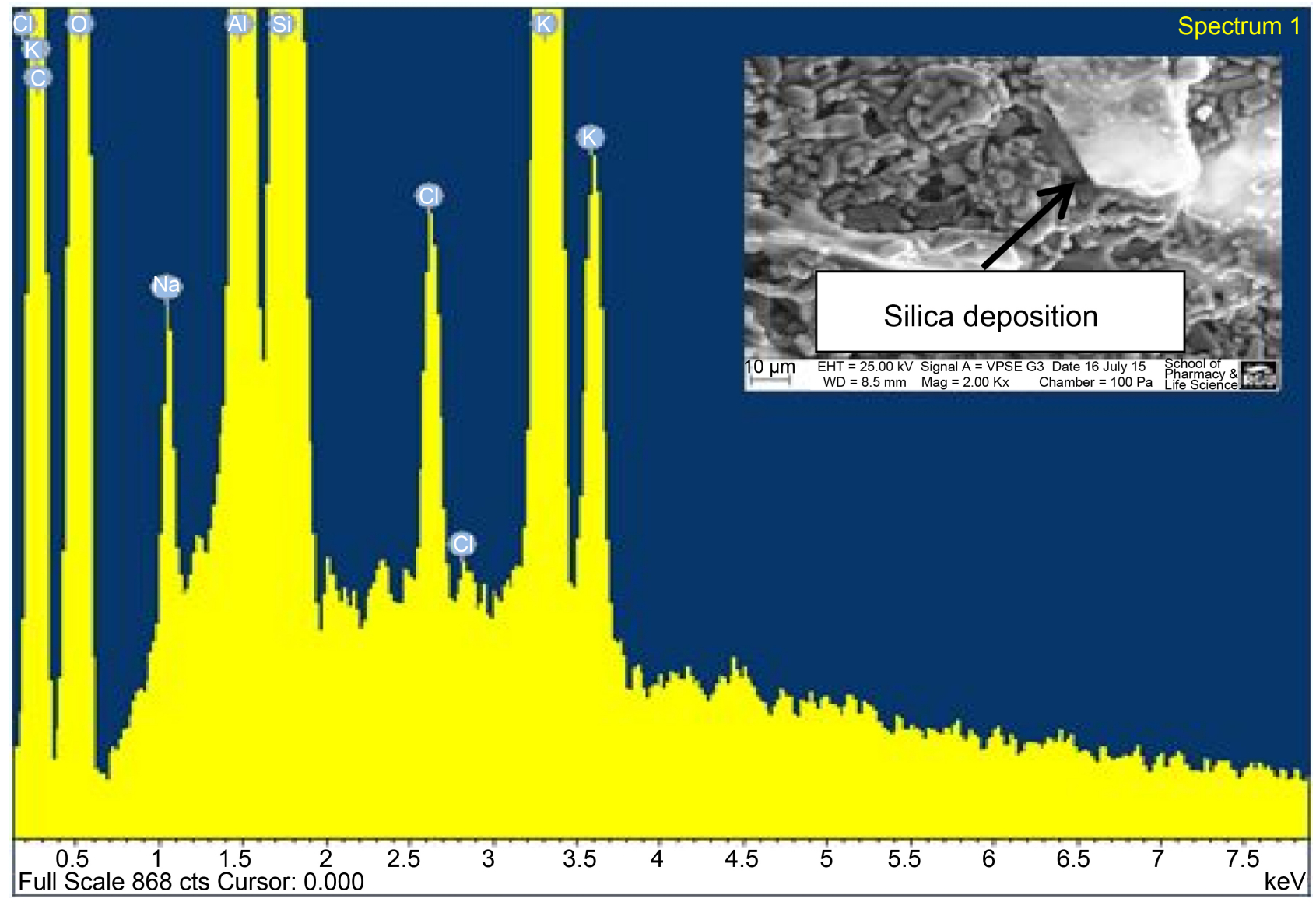

Figure 11. SEM image and EDAX of the silica membrane that was used for the characterisation.

Table 3. BET curve summary for the $5^{\text {th }}$ and $6^{\text {th }}$ dip-coated membranes.

\begin{tabular}{ccc}
\hline Parameters & $5^{\text {th }}$ dip-coating & $6^{\text {th }}$ dip-coating \\
\hline Slope & 3005.934 & $521,655.829$ \\
Intercept & $-1.812 \mathrm{e}+03$ & $-1.245 \mathrm{e}+04$ \\
Correlation coefficient $\left(R^{2}\right)$ & 0.71414 & 1.00000 \\
C, constant & -0.659 & -3.191 \\
Surface Area $\left(\mathrm{m}^{2} / \mathrm{g}\right)$ & 2.916 & 0.088 \\
\hline
\end{tabular}

seen that the silica was evenly distributed on the surface of the membrane after the modification process. The whitish background on the surface image was suggested to be the silica used for the membrane modification. However, the membrane also exhibited a clear surface which also indicated that it was defect-free. The result was further confirmed by the EDAX result for the membrane sample. From the result obtained in Figure 11, it was found that the membrane exhibited different elements on the spectra including oxygen, carbon, potassium, chlorine, aluminium and silicon. The fresh support is made up of $\mathrm{Al}_{2} \mathrm{O}_{3}$, used for the fabrication of the support. However due to the silica modification, $\mathrm{Si}, \mathrm{O}, \mathrm{C}$ and other elements were identified from the EDAX spectra. So a combination of $\mathrm{Si}$ and $\mathrm{O}$ was suggested to be $\mathrm{SiO}_{2}$ originating from the solution 
that was used for coating the surface of the support. From the EDAX result, it was suggested that the fresh support was initially coated with aluminium oxide and then subsequently coated with silicon oxide after the modification process.

\section{Conclusion}

A repeat dip-coating process has been used to prepare silica membranes on alumina support. The morphology and hydrodynamic characteristics of the silica membrane was carried out using different analytical methods including liquid nitrogen adsorption, scanning electron microscopy/energy dispersive analyser and gas permeation respectively. Helium gas with the highest permeation rate was found as the most suitable carrier gas for analysis esterification product. Ar, $\mathrm{N}_{2}$ and $\mathrm{CO}_{2}$ gases showed a linear proportionality with the inverse square root of the molecular weight of the different gases. The permeance of the four gases was found to decrease with increase in gauge pressure confirming Knudsen flow mechanism. The average pore size of the silica membrane was found to reduce after the modification process. The calculated pore radius of the four gases was found to be smaller than the mean free path. The membrane pore size was in accordance with IUPAC classification. The order of the gas flow rate with respect to the gauge pressure was $\mathrm{He}(2 \mathrm{~g} / \mathrm{mol})>\mathrm{N}_{2}(28 \mathrm{~g} / \mathrm{mol})>\operatorname{Ar}(40 \mathrm{~g} / \mathrm{mol})>$ $\mathrm{CO}_{2}(44 \mathrm{~g} / \mathrm{mol})$. The SEM surface morphology of the membrane showed the distribution of silica on the membrane surface. The EDAX of the silica membrane showed different elements including $\mathrm{Al}, \mathrm{Si}$ and $\mathrm{O}$. The gas flow rate showed an increase with respect to gauge pressure.

\section{Acknowledgements}

The author wishes to express sincere thanks to CPIMT for supplying the membrane and other infrastructures used in the study, school of pharmacy and life science, RGU for the SEM/EDAX examination. Additionally, PTDF is great fully acknowledged for their financial support towards the research work.

\section{References}

[1] Calvo, J.I., Bottino, A., Capannelli, G. and Hernández, A. (2008) Pore Size Distribution of Ceramic UF Membranes by Liquid-Liquid Displacement Porosimetry. Journal of Membrane Science, 310, 531-538. https://doi.org/10.1016/j.memsci.2007.11.035

[2] Smart, S., Liu, S., Serra, J.M., Diniz da Costa, J.C., Iulianelli, A. and Basile, A. (2013) 8-Porous Ceramic Membranes for Membrane Reactors. In: Basile, A., Ed., Handbook of Membrane Reactors, Woodhead Publishing, Cambridge, 298-336. https://doi.org/10.1533/9780857097330.2.298

[3] Bai, C., Jia, M., Falconer, J.L. and Noble, R.D. (1995) Preparation and Separation Properties of Silicalite Composite Membranes. Journal of Membrane Science, 105, 79-87. https://doi.org/10.1016/0376-7388(95)00049-I

[4] Jiang, H., Meng, L., Chen, R., Jin, W., Xing, W. and Xu, N. (2013) Progress on Porous Ceramic Membrane Reactors for Heterogeneous Catalysis over Ultrafine and Nano-Sized Catalysts. Chinese Journal of Chemical Engineering, 21, 205-215. https://doi.org/10.1016/S1004-9541(13)60460-7 
[5] Abedini, R. and Nezhadmoghadam, A. (2001) Application of Membrane in Gas Separation Processes: Its Suitability and Mechanisms. Petroleum and Coal, 52, 69-80.

[6] Javaid, A. (2005) Membranes for Solubility-Based Gas Separation Applications. Chemical Engineering Journal, 112, 219-226.

https://doi.org/10.1016/j.cej.2005.07.010

[7] Lee, D. and Oyama, S.T. (2002) Gas Permeation Characteristics of a Hydrogen Selective Supported Silica Membrane. Journal of Membrane Science, 210, 291-306. https://doi.org/10.1016/S0376-7388(02)00389-7

[8] Marković, A., Stoltenberg, D., Enke, D., Schlünder, E. and Seidel-Morgenstern, A. (2009) Gas Permeation through Porous Glass Membranes: Part II: Transition Regime between Knudsen and Configurational Diffusion. Journal of Membrane Science, 336, 32-41. https://doi.org/10.1016/j.memsci.2009.02.030

[9] Wang, M., Wang, Z., Li, N., Liao, J., Zhao, S., Wang, J., et al. (2015) Relationship between Polymer-Filler Interfaces in Separation Layers and Gas Transport Properties of Mixed Matrix Composite Membranes. Journal of Membrane Science, 495, 252-268. https://doi.org/10.1016/j.memsci.2015.08.019

[10] Phattaranawik, J., Jiraratananon, R. and Fane, A. (2003) Effect of Pore Size Distribution and Air Flux on Mass Transport in Direct Contact Membrane Distillation. Journal of Membrane Science, 215, 75-85. https://doi.org/10.1016/S0376-7388(02)00603-8

[11] Singh, R.P., Way, J.D. and McCarley, K.C. (2004) Development of a Model Surface Flow Membrane by Modification of Porous Vycor Glass with a Fluorosilane. Industrial \& Engineering Chemistry Research, 43, 3033-3040. https://doi.org/10.1021/ie030679q

[12] Li, K. (2007) Ceramic Membranes for Separation and Reaction. John Wiley \& Sons, Hoboken. https://doi.org/10.1002/9780470319475

[13] Ismail, A.F. and David, L. (2001) A Review on the Latest Development of Carbon Membranes for Gas Separation. Journal of Membrane Science, 193, 1-18. https://doi.org/10.1016/S0376-7388(01)00510-5

[14] Pandey, P. and Chauhan, R. (2001) Membranes for Gas Separation. Progress in Polymer Science, 26, 853-893. https://doi.org/10.1016/S0079-6700(01)00009-0

[15] Basu, A., Akhtar, J., Rahman, M. and Islam, M. (2004) A Review of Separation of Gases Using Membrane Systems. Petroleum Science and Technology, 22, 13431368. https://doi.org/10.1081/LFT-200034156

[16] Weidenthaler, C. (2011) Pitfalls in the Characterization of Nanoporous and Nanosized Materials. Nanoscale, 3, 792-810. https://doi.org/10.1039/c0nr00561d

[17] Edward, G. (2006) Apparatus and Method for Separating Gases. US Patent No. $7,048,778$ B2.

[18] Edward, G. (2007) Apparatus and Method for Separating Gases. US Patent No. 7,048,778 B2.

[19] Zhu, J., Fan, Y. and Xu, N. (2011) Modified Dip-Coating Method for Preparation of Pinhole-Free Ceramic Membranes. Journal of Membrane Science, 367, 14-20. https://doi.org/10.1016/j.memsci.2010.10.024

[20] Vospernik, M., Pintar, A., Berčič, G., Batista, J. and Levec, J. (2004) Potentials of Ceramic Membranes as Catalytic Three-Phase Reactors. Chemical Engineering Research and Design, 82, 659-666. https://doi.org/10.1205/026387604323142720

[21] Okon, E., Kajama, M.N. and Gobina, E. (2014) Gas Permeation on Silica Membrane for Lactic Acid Esterification Applications. Journal of Energy, 1, 265-269. 
[22] Benito, J.M., Conesa, A., Rubio, F. and Rodriguez, M.A. (2005) Preparation and Characterisation of Tubular Ceramic Membranes for Treatment of Oil Emulsions. Journal of the European Ceramic Society, 25, 1853-1903. https://doi.org/10.1016/j.jeurceramsoc.2004.06.016

[23] Okon, E., Shehu, H. and Gobina, E. (2015) Gas Transport through Inorganic Ceramic Membrane and Cation-Exchange Resins Characterization for Ethyl Lactate Separation. Transaction on Engineering Technologies, 6, 403-414. https://doi.org/10.1007/978-94-017-7236-5_29

[24] Okon, E., Shehu, H. and Gobina, E. (2015) Characterisation of Inorganic Composite Ceramic Membrane for Lactic Acid Esterification Processes. Advanced Materials Research, 1102, 99-102. https://doi.org/10.4028/www.scientific.net/AMR.1102.99

[25] Marković, A., Stoltenberg, D., Enke, D. and Schlünder, E. (2009) Gas Permeation through Porous Glass Membranes: Part I. Mesoporous Glasses-Effect of Pore Diameter and Surface Properties. Journal of Membrane Science, 336, 17-31.

https://doi.org/10.1016/j.memsci.2009.02.031 


\section{Nomenclature}

$P_{1}=$ absolute pressure $(\mathrm{Pa})$

$P_{2}=$ atmospheric pressure $(\mathrm{Pa})$

$\mu=$ gas viscosity $\left(\mathrm{Pa} \cdot \mathrm{s}^{-1}\right)$

$L=$ membrane wall thickness $(\mathrm{m})$

$r=$ membrane pore size $(\mathrm{m})$

$R=$ gas molar constant $\left(\mathrm{J} \cdot \mathrm{mol}^{-1} \cdot \mathrm{K}^{-1}\right)$

$T=$ atmospheric temperature $(\mathrm{K})$.

$D=$ Knudsen diffusion $\left(\mathrm{m}^{2} / \mathrm{s}\right)$

$\varepsilon=$ porosity of the membrane (\%)

$R=$ gas molar constant $\left(\mathrm{J} \cdot \mathrm{mol}^{-1} \cdot \mathrm{K}^{-1}\right)$

$M=$ the molar weight of the diffusing gas $(\mathrm{g} / \mathrm{mol})$

$\delta \rho=$ pore diameter $(\mathrm{m})$

$\tau=$ tortuosity $(\mathrm{m})$

$T=$ temperature $(\mathrm{K})$

$\pi=3.142$.

$\tau_{p}=$ membrane pore radius $(\mathrm{m})$

$\lambda=$ mean free path $(\mathrm{m})$

$k=$ Boltzmann constant $\left(\left(\mathrm{J} \cdot \mathrm{K}^{-1}\right)\right)$,

$d=$ collision diameter $(\mathrm{m})$

$A=$ membrane area $\left(\mathrm{m}^{2}\right)$

$p=$ theoretical density of alumina $\left(3.95 \times 10^{-3} \mathrm{~kg} \cdot \mathrm{m}^{-3}\right)$

$W_{1}=$ initial weight of the alumina support $(\mathrm{g})$

$W_{2}=$ total weight of the support and membrane $(\mathrm{g})$.

$Q_{i}=$ gas permeance $\left(\mathrm{mol} \cdot \mathrm{m}^{-2} \cdot \mathrm{s}^{-1} \cdot \mathrm{Pa}^{-1}\right)$

$\Delta P=$ pressure drop across the membrane (bar)

$J=$ Gas flux $\left(\mathrm{mol} \cdot \mathrm{m}^{-2} \cdot \mathrm{s}^{-1}\right)$

$F=$ permeability $\left(\mathrm{mol} \cdot \mathrm{m}^{-2} \cdot \mathrm{s}^{-1} \cdot \mathrm{Pa}^{-1} \cdot \mathrm{m}\right)$

$A o=$ constant representing viscous flow from the permeability graph

$B=$ constant representing Knudsen flow from the permeability graph.

Scientific Research Publishing

Submit or recommend next manuscript to SCIRP and we will provide best service for you:

Accepting pre-submission inquiries through Email, Facebook, LinkedIn, Twitter, etc. A wide selection of journals (inclusive of 9 subjects, more than 200 journals)

Providing 24-hour high-quality service

User-friendly online submission system

Fair and swift peer-review system

Efficient typesetting and proofreading procedure

Display of the result of downloads and visits, as well as the number of cited articles

Maximum dissemination of your research work

Submit your manuscript at: http://papersubmission.scirp.org/

Or contact msce@scirp.org 